\title{
A Study of Psychosocial and Economic Impact of COVID 19 Pandemic among Sanitation Workers of a Tertiary Care Hospital
}

\author{
Khader Mohammad Ali $\mathrm{S}^{1}$, Venkateswarlu $\mathrm{U}^{2}$, Cynthia Subhaprada $\mathrm{S}^{3^{*}}$, Sreedevi $\mathrm{A}^{4}$ \\ ${ }_{1}^{1}$ st Year Postgraduate, Department of Community Medicine Kurnool Medical College, Andhra Pradesh India \\ ${ }^{2}$ Assistant Professor, Department of Community Medicine Kurnool Medical College, Andhra Pradesh India \\ ${ }^{3}$ Associate Professor, Department of Community Medicine Kurnool Medical College, Andhra Pradesh India \\ ${ }^{4}$ Professor and HOD, Department of Community Medicine Kurnool Medical College, Andhra Pradesh India
}

\section{Article History \\ Received: 10.11 .2020 \\ Accepted: 23.11.2020 \\ Published: 28.11.2020}

Journal homepage:

https://www.easpublisher.com

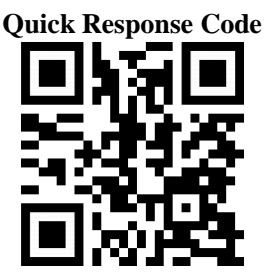

Abstract: Covid-19 pandemic has a great psychosocial impact on society, due to fear of infection and disturbed the economy of the people. The aim of the study is to assess the psychosocial and economic impact of Covid-19 pandemic among sanitation workers of a tertiary care hospital. A cross sectional study was carried out from August 2020 to September 2020 at Kurnool Medical College, Kurnool. In previous studies, 75\% of study subjects responded that Covid-19 has a serious psychosocial and economic impact. Considering prevalence of $75 \%$ and $20 \%$ of allowable error, sample size arrived at is 33.4 , using the formula $4 \mathrm{pq} / \mathrm{l}^{2}$. Out of 100 sanitation workers of one outsourcing agency, 30 workers who fulfilled inclusion criteria of one year work experience and with at least one school going child, were selected by simple random sampling. IEC clearance, permission from the work supervisor and informed consent from the study subjects was obtained. Data collected using a semi structured questionnaire was analysed using MS Excel-2016 version. Majority were in the age group of 31-40 years $(63.33 \%)$. Most of them were females (90\%), $50 \%$ were literates. Decreased family income was noticed among $60 \%$ of study subjects and decrease in savings among 76.6\%. 70\% had fear of sickness and $73.33 \%$ responded that their children's education was affected. Assurance of job security and social security measures at the work place would help these workers during such pandemics.

Keywords: Covid-19, psychosocial impact, sanitation workers, fear, pandemic.

Copyright (C) 2020 The Author(s): This is an open-access article distributed under the terms of the Creative Commons Attribution 4.0 International License (CC BY-NC 4.0) which permits unrestricted use, distribution, and reproduction in any medium for non-commercial use provided the original author and source are credited.

\section{INTRODUCTION}

Human history is observing a very strange time fighting an invisible enemy, the novel COVID -19. Initially observed in the Wuhan province of china, now spreaded all over the world. On the 30 January 2020, the WHO declared the health outbreak caused by COVID-19 a public health emergency of international concern. World Health Organization (WHO) announced COVID-19 as a global pandemic on March 11th, 2020. On 24 March 2020, the government of India under Prime Minister, Narendra Modi ordered a nationwide lockdown for 21 days and further lockdown in phases, this whole situation has drastically changed the life of people living in India in a matter of days. The population is experiencing a new, unpredictable and rapidly evolving situation. They were confined to stay at home, family dynamics have remarkably changed, travel was restricted, and there has been a reduction in leisure activities and social life. The work situation has also changed thoroughly; many people have temporary or permanently lost their jobs, many worked from home, sometimes with insufficient preparation for doing so, and those who work in sectors considered essential appear to experience heavy workloads, increased levels of stress and a greater exposure to the virus. COVID -19 pandemic along with high infectivity is also shown to have psychosocial and economic impact among sanitation workers who are playing important role in maintaining hygiene in the hospital [1, 2]. The income and expenditure of the sanitation workers has been intensely affected by COVID -19 . While psychological support is being provided to patients and healthcare workers, the sanitation worker's mental health requires significant attention as well Previous outbreaks have reported that psychological impact of quarantine can vary from immediate effects, like irritability, fear of contracting and spreading infection to family members, anger, confusion, frustration, loneliness, denial, anxiety, depression, insomnia, etc. Hence this study aims to describe the psychosocial and economic impact of COVID -19 among sanitation workers in a tertiary care hospital. 


\section{Methodology}

A Cross sectional study was done at Kurnool Medical College among 30 sanitation workers in the months of August and September 2020 using pre structured Questionnaire and IEC Clearance was obtained (Letter/IEC No.10/2020-KMC, dt: 14-092020). Sample size was calculated by using the formula $4 \mathrm{pq} / \mathrm{l}^{2}$. Prevalence was $75 \%$ taken from previous studies, allowable error taken as $20 \%$ [3, 4]. Sample size arrived at is 33.4

\section{Inclusion criteria}

1. Sanitation workers belonging to one particular outsourcing agency.

2. One year work experience at Kurnool Medical College.

3. At least having one school going child.

\section{Exclusion criteria}

1. Those that did not fulfill inclusion criteria.

\section{Statistical Analysis}

Data entered and analyzed by using MS Excel version 16, Chi-square test was applied to test the significance. P-value less than 0.05 were considered as statistically significant.

\section{ReSUlTS}

The study was done in 30 sanitation workers of Kurnool Medical College at Kurnool, Andhra Pradesh. The results of the study are as follows:

Table-1: Age distribution among study participants

\begin{tabular}{|l|l|}
\hline Age distribution & Percentage of study participants \\
\hline $20-30$ years & $20 \%$ \\
\hline $31-40$ years & $63.33 \%$ \\
\hline $41-50$ years & $13.33 \%$ \\
\hline$>60$ years & $3.33 \%$ \\
\hline
\end{tabular}

Majority were in the age group of 31-40 years $(63.33 \%)$. About $90 \%$ of the participants are females and $10 \%$ are males. $50 \%$ of the study participants were literates

Table-2: Effect on economy in study participants

\begin{tabular}{|l|c|c|c|}
\hline Economic variants of the study participant & Increased & Decreased & No Change \\
\hline Income & - & - & $100 \%$ \\
\hline Family income & $6.66 \%$ & $60 \%$ & $33.3 \%$ \\
\hline Expenditure & $100 \%$ & - & - \\
\hline Family expenditure & $100 \%$ & - & - \\
\hline Savings of family & - & $76.66 \%$ & $23.33 \%$ \\
\hline
\end{tabular}

All the participants income was not changed in the pandemic but $60 \%$ of the participants family income was decreased due to pandemic, the expenditure and family expenditure was increased all the 30 study participants. Savings of the study participant's family was decreased in $76.66 \%$ of the sanitation workers due to the pandemic.

Table-3: Fear of covid-19 in study participants

\begin{tabular}{|l|c|}
\hline \multicolumn{1}{|c|}{ Type of Fear } & Percentage of People \\
\hline Fear of sickness & $70 \%$ \\
\hline Fear of isolation from family and society & $16.66 \%$ \\
\hline Fear of death & $13.33 \%$ \\
\hline
\end{tabular}

About $70 \%$ of the study participants were observed to have fear of sickness due to covid-19, $16.66 \%$ of participants have fear of isolation from family and society and $13.33 \%$ of them were having fear of death due to covid-19.

Table-4: Work and Sleep pattern in study participants

\begin{tabular}{|c|c|c|c|}
\hline Pattern & Increased & Decreased & No change \\
\hline Work Pattern & $70 \%$ & $13.33 \%$ & $16.66 \%$ \\
\hline Sleep Pattern & - & $26.6 \%$ & $73.33 \%$ \\
\hline
\end{tabular}

In $70 \%$ of the sanitation workers increased in work pattern was observed, Sleep pattern was decreased in $26.66 \%$ of the study participants, about $16.66 \%$ of sanitation workers have job loss in their family. Social gathering in break time during work was decreased in $66.66 \%$ of the sanitation workers. $90 \%$ of study participants are not having co-morbidities like hypertension, diabetes and thyroid disorders but $10 \%$ of 
them have co-morbidities and their health care is not affected by covid-19 pandemic.

All the study participants were taking precautionary measures by social distancing, sanitizers and by using mask. About $73.33 \%$ of study participant's children's education is affected by Covid-19 pandemic.

\section{DISCUSSION}

In a study on general population in Spain, $3.2 \%$ lost their jobs and more than $42 \%$ perceived a risk of decreased income in the pandemic, while in present study $16.66 \%$ participants have job loss in their family and $60 \%$ of participants family income is decreased [4]. One study showed that the psychological distress was higher among non-medical workers in hospitals while in present study there were $30 \%$ participants feeling stress in work [5].

\section{CONCLUSION}

The sanitation workers expenditure was very much increased and family income has been decreased with savings affected, along with this the fear of COVID-19 was observed. The following measures can be taken to help the sanitation workers:

Job security and social security measures need to be taken, there is need to provide economic support by increasing salary to the sanitation workers who are working hard in the pandemic. Insurance policies for sanitation workers who work in COVID -19 hospitals. Transport facilities are needed for them to decrease expenditure by travelling. Accommodation facilities should be provided to sanitation workers coming from far places. Some social support is needed for them to avoid the fear of infection. More recruitment of workers is needed to decrease the workload in the COVID-19 Pandemic.

\section{Limitations of the study}

This study is done in sanitation workers of Kurnool Medical College, so the results cannot be general population. The study is conducted in sanitation workers belonging to one particular outsourcing agency.

\section{ACKNOWLEDGEMENTS}

My sincere thanks to the Principal Dr.P.Chandra Sekhar, MD., DM (cardio) and IEC for permitting us to conduct this study, faculty and seniors of Department of Community Medicine and Study participants

\section{REFERENCES}

1. Dubey, S., Biswas, P., Ghosh, R., Chatterjee, S., Dubey, M. J., Chatterjee, S., \& Lavie, C. J. (2020). Psychosocial impact of COVID-19. Diabetes \& Metabolic Syndrome: Clinical Research \& Reviews.

2. Xiong, J., Lipsitz, O., Nasri, F., Lui, L. M., Gill, H., Phan, L., \& McIntyre, R. S. (2020). Impact of COVID-19 pandemic on mental health in the general population: A systematic review. Journal of affective disorders.

3. Bodrud-Doza, M., Shammi, M., Bahlman, L., Islam, A. R. M., \& Rahman, M. (2020). Psychosocial and socio-economic crisis in Bangladesh due to COVID-19 pandemic: a perception-based assessment. Frontiers in public health, 8, 341.

4. Rodríguez-Rey, R., Garrido-Hernansaiz, H., \& Collado, S. (2020). Psychological impact and associated factors during the initial stage of the coronavirus (COVID-19) pandemic among the general population in Spain. Frontiers in psychology, 11, 1540.

5. Luo, M., Guo, L., Yu, M., \& Wang, H. (2020). The Psychological and Mental Impact of Coronavirus Disease 2019 (COVID-19) on Medical Staff and General Public-A Systematic Review and Metaanalysis. Psychiatry Research, 113190. 